\title{
Inhibitory Effect of Cow Urine Extracts of Selected Plants against Pathogens Causing Rhizome Rot of Ginger
}

\author{
Rakesh KN ${ }^{1}$, Dileep $\mathbf{N}^{1}$, Syed Junaid ${ }^{1}$, Prashith Kekuda TR ${ }^{1}$, Vinayaka $\mathrm{KS}^{2^{\star}}$, Noor Nawaz $\mathrm{AS}^{3}$ \\ ${ }^{1}$ Department of Microbiology, SRNMN College of Applied Sciences, NES Campus, Balraj Urs Road, \\ Shivamogga-577201, Karnataka, India \\ 2 Department of Botany, Indira Gandhi Government College, Sagara- 577401, Karnataka, India \\ ${ }^{3}$ Organic Farming Research Centre, ZARS, Navile, Shivamogga-577204, Karnataka, India
}

\begin{tabular}{|c|c|}
\hline \multirow{4}{*}{$\begin{array}{l}\text { Abstract } \\
\text { The present study was carried out to investigate the inhibitory effect of cow urine extracts } \\
\text { of nine plants against two fungi viz., Fusarium oxysporum f.sp. zingiberi, Pythium } \\
\text { aphanidermatum and a bacterium Ralstonia solanacearum that are known to cause } \\
\text { rhizome rot of ginger. Antifungal and antibacterial activity of cow urine extracts was } \\
\text { investigated by poison food technique and agar well diffusion method respectively. The } \\
\text { extent of growth of test fungi in plates poisoned with extracts was lesser when compared } \\
\text { with the control plates. Among fungi, high susceptibility was recorded in case of } F \text {. } \\
\text { oxysporum. Cow urine extract of Elaegnus kologa caused high inhibition of } P \text {. } \\
\text { aphanidermatum whereas cow urine extract of Artocarpus lakoocha, Hemidesmus indicus, } \\
\text { Croton roxburghii and Maesa indica caused high inhibition of } F \text {. oxysporum. All extracts } \\
\text { caused inhibition of } R \text {. solanacearum. Extract of } A \text {. lakoocha caused maximum inhibition } \\
\text { followed by } H \text {. indicus, E. kologa and others. Overall, cow urine extracts of plants selected } \\
\text { in this study caused varied inhibition of test microbes. These extracts may find a possible } \\
\text { application in agriculture against phytopathogenic microorganisms. }\end{array}$} & \\
\hline & $\begin{array}{ll}\text { Received : }: 15-04-2013 \\
\text { Revised : 16-06-2013 } \\
\text { Accepted : 19-06-2013 }\end{array}$ \\
\hline & \\
\hline & \\
\hline
\end{tabular}

\section{INTRODUCTION}

Microorganisms cause a number of diseases in crops than any other pathogens and results in major crop losses. The harvest losses of crops are much higher in developing countries. Pathogens such as species of Fusarium, Alternaria, Pythium, Sclerotium, Phytophthora, Curvularia, Botrytis, Ralstonia, Xanthomonas etc., cause severe damages to agricultural crops before and after harvesting. The plant diseases caused by microorganisms are usually controlled by the use of chemicals. However, the use of synthetic compounds to control phytopathogens suffers from two main drawbacks viz., potential development of resistance in pathogens and the risk of toxicity. Due to this, research focused on compounds derived from natural sources such as plant extracts and their possible application in agriculture is being intensified. Many natural products, including plant extracts, have been shown to possess marked inhibitory activity against a variety of pathogens (Ojala et al., 2000; Benkeblia, 2004; Bhai et al.,
2005; Bajpai et al., 2008; Paret et al., 2010; Ranaware et al., 2010; Zhao et al., 2011; Tiwari and Das, 2011; Bhardwaj et al., 2011; De Britto et al., 2011).

From the ancient period in India, cow urine has been used for several medicinal purposes and the description on its use has been in several classical Ayurveda texts like Charaka samhita and Shushruta samhita. Cow is believed to be a sacred animal in India its urine is known to cure several diseases. In Veda, cow urine is compared with the nectar (Krishnamurthi et al., 2004; Gururaja et al., 2011). Cow urine has got applications in agriculture. It has been found that cow urine has potential to control Meloidogyne incognita in Lycopersicon esculentus (Abubakar et al., 2004) and aphids and pickleworms in watermelon cultivation (Burubai and Eribo, 2012). It is observed that cow urine has inhibitory effect against several plant pathogens such as Sclerotinia sclerotiorum (Basak et al., 2002a), Fusarium solani 
Rakesh et al.,

f.sp. cucurbitae (Basak et al., 2002b), Bipolaris sorokiniana (Akhter et al., 2006) and Xanthomonas oryzae pv. oryzae (Murugan et al., 2012). It has been shown that cow urine extract of certain plants as well as cow urine in combination with certain plant extracts are found to possess marked inhibitory effect on human pathogens as well as plant pathogens (Akhter et al., 2006; Yadav et al., 2008; Rajapandiyn et al., 2011; Tiwari \& Das, 2011).

Ginger (Zingiber officinale Rosc., Zingiberaceae) is an important commercial crop grown for its aromatic rhizomes being used as spice and medicine. India is the largest producer of ginger and accounts for about $1 / 3^{\text {rd }}$ of total world output. Ginger is grown in Kerala, Karnataka, West Bengal, Andhra Pradesh, Orissa, Arunachal Pradesh, Sikkim and other parts of India (Kumar et al., 2008; Sharma et al., 2010). The production of ginger is influenced largely by a number of diseases caused by bacteria, fungi, viruses, mycoplasma and nematodes. Main diseases of ginger are bacterial wilt caused by Ralstonia solanacearum, rhizome rot caused by Pythium species, Fusarium species, Sclerotium species, Pseudomonas species and others (Dake and Edison, 1989; Senapati and Ghose, 2005; Paret et al., 2010; Sharma et al., 2010; Kavyashree, 2009). Soft rot is a serious disease and has drastic effects on crop and eventually leads to rhizome loss. It is manifested initially by foliar yellowing and later water soaked lesions appears on the collar of the pseudostem which extend to rhizomes and leaves resulting in rotting of the entire plant. The disease is both seed and soil-borne (Bhai et al., 2005). In the present study, we have determined the inhibitory activity of cow urine extracts of selected plants against the pathogens viz., Fusarium oxysporum f.sp. zingiberi, Pythium aphanidermatum and Ralstonia solanacearum causing rhizome rot of ginger.

\section{MATERIALS AND METHODS}

\section{Collection of Cow Urine}

Urine was collected in a sterile container from a local cow variety called Malnad gidda at early morning 6:30am. The urine was filtered through Whatman No. 1 and stored in airtight container.

\section{Preparation of Cow Urine Extract of Selected Plants}

Table 1 represents the plants used in the present study. The plants were shade dried, powdered mechanically and used for preparation of extract. A known quantity $(10 \mathrm{~g})$ of powdered plant material was added to $100 \mathrm{ml}$ of cow urine and left for 15 days. Later, the contents were filtered through muslin cloth followed by Whatman no. 1 and the filtrates were stored in refrigerator until use.
Sci. Technol. Arts Res. J., April-June 2013, 2(2): 92-96

Table 1: Plants used in the study.

\begin{tabular}{|c|c|c|}
\hline Name of the plant & Family & $\begin{array}{l}\text { Part } \\
\text { used }\end{array}$ \\
\hline Artocarpus lakoocha Roxb. & Moraceae & Leaf \\
\hline Maesa indica (Roxb.) Wallich & Myrsinaceae & Leaf \\
\hline Polyalthia longifolia Thw. & Annonaceae & Leaf \\
\hline Hemedesmus indicus $\mathrm{R} . \mathrm{Br}$ & Asclepiadaceae & Root \\
\hline $\begin{array}{l}\text { Swertia chirata } \\
\text { (Roxb. ex Fleming) H. Karst. }\end{array}$ & Gentianaceae & $\begin{array}{l}\text { Whole } \\
\text { plant }\end{array}$ \\
\hline Croton roxburghii Balak. & Euphorbiaceae & Leaf \\
\hline Elaegnus kologa Schlecht & Elaeagnaceae & Leaf \\
\hline Gnidia glauca (Fresen.) Gilg & Thymelaeaceae & Leaf \\
\hline Fahrenheitia zeylanica (Thw.) & Euphorbiaceae & Leaf \\
\hline
\end{tabular}

\section{Antifungal Activity}

Poisoned food technique was employed to screen the antifungal efficacy of cow urine extracts of selected plants (Dileep et al., 2013). In brief, Potato dextrose agar (HiMedia, Mumbai) media amended with cow urine extracts $(10 \%)$ were autoclaved and poured into sterile petriplates. Fungal discs of $5 \mathrm{~mm}$ diameter were cut with the help of sterile cork borer from the periphery of 5 days old culture of $F$. oxysporum f. sp. zingiberi and $P$. aphanidermatum and the discs were transferred aseptically on PDA plates poisoned with cow urine extracts and incubated for 5 days at $28^{\circ} \mathrm{C}$. Colony diameters in mutual perpendicular directions were measured on the $5^{\text {th }}$ day with the help of a ruler. The experiment was repeated two times and average colony diameter was noted. Antifungal activity of cow urine extracts was recorded in terms of inhibition of mycelial growth (\%) and was calculated using the formula:

Mycelial growth inhibition $(\%)=(\mathrm{C}-\mathrm{T} / \mathrm{C}) \times 100$ where ' $C$ ' is average colony diameter in control plates and ' $T$ ' is average colony diameter in poisoned plates.

\section{Antibacterial Activity}

In order to assess antibacterial activity of cow urine extracts against $R$. solanacearum, we have employed Agar well diffusion method (Kekuda et al., 2012). The bacterium was inoculated into sterile Nutrient broth (HiMedia, Mumbai) tubes and incubated for 24 hours at $37^{\circ} \mathrm{C}$. The broth culture was swabbed on sterile Nutrient agar (HiMedia, Mumbai) plates using sterile cotton swabs. With the help of a sterile cork borer, wells of $0.6 \mathrm{~cm}$ diameter were punched in the inoculated plates and cow urine extracts and standard (Streptomycin, $1 \mathrm{mg} / \mathrm{ml}$ ) were transferred into respectively labeled wells. The plates were incubated at $37^{\circ} \mathrm{C}$ for 24 hours and the zone of inhibition formed around the wells was measured. The experiment was repeated twice and the average value was recorded. 
Rakesh et al.,

\section{RESULTS}

The result of inhibitory effect of cow urine extracts of selected plants against $F$. oxysporum and $P$. aphanidermatum is presented in Table 2 and Figure 1. The growth of test fungi, in terms of diameter of the fungal colony in poisoned plates was measured and compared with the control plates. The colony diameter of test fungi was lesser in poisoned plates in comparison with that of colony diameter in control plates indicating antifungal potential of cow urine extract of plants. The test fungi were found to be sensitive to all the extracts. Among fungi, high susceptibility was recorded in case of $F$. oxysporum with growth inhibition of $>50 \%$ produced by all extracts. Only 3 extracts caused $>50 \%$ inhibition of $P$. aphanidermatum. Cow urine extract of $E$. kologa \& $P$. longifolia caused high and least inhibition of $P$. aphanidermatum respectively. In case of $F$. oxysporum, higher inhibition was produced by $A$. lakoocha, $H$. indicus, C. roxburghii and $M$. indica.

Table 2: Antifungal activity of Cow urine extracts of selected plants.

\begin{tabular}{lcc}
\hline \multirow{2}{*}{$\begin{array}{c}\text { Cow Urine } \\
\text { Extract }\end{array}$} & \multicolumn{2}{c}{ Colony diameter in cm } \\
\cline { 2 - 3 } & P. aphanidermatum & F. oxysporum \\
\hline Control & 2.8 & 3.1 \\
A. lakoocha & 1.1 & 0.8 \\
H. indicus & 1.6 & 0.8 \\
E. kologa & 1.0 & 1.0 \\
G. glauca & 1.8 & 1.2 \\
P. longifolia & 1.9 & 0.9 \\
C. roxburghii & 1.5 & 0.8 \\
F. zeylanica leaf & 1.1 & 0.9 \\
S. chirata & 1.8 & 1.1 \\
M.indica & 1.7 & 0.8 \\
\hline
\end{tabular}

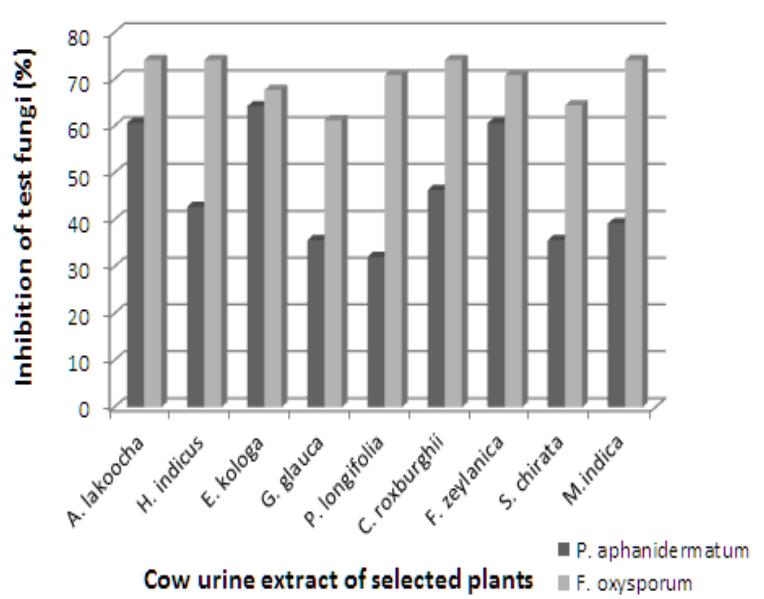

Figure 1: Inhibition of test fungi (\%) by Cow urine extracts of selected plants.
Sci. Technol. Arts Res. J., April-June 2013, 2(2): 92-96

The efficacy of cow urine extracts of plants to inhibit phytopathogenic bacterium $R$. solanacearum was evaluated by agar well diffusion method. The presence of zone of inhibition around the well was considered positive for antibacterial activity. It was found that the bacterium was susceptible to all extracts. Among extracts, extract of A. lakoocha caused maximum inhibition followed by $H$. indicus, E. kologa and others. Least inhibition of the bacterium was recorded in case of $S$. chirata and $M$. indica (Table 3).

Table 3: Antibacterial activity Cow urine extracts against $R$. solanacearum.

\begin{tabular}{lc}
\hline Cow Urine Extract & Zone of Inhibition (cm) \\
\hline A. lakoocha & 2.5 \\
H. indicus & 2.0 \\
E. kologa & 1.9 \\
G. glauca & 1.4 \\
P. longifolia & 1.2 \\
C. roxburghii & 1.8 \\
F. zeylanica & 1.2 \\
S. chirata & 0.8 \\
M.indica & 0.8 \\
Streptomycin & 3.2 \\
\hline
\end{tabular}

\section{DISCUSSION}

The term rhizome rot of ginger is accepted generally for soft rot and yellow disease complex as soft rot and yellows are generally found together affecting the plants and symptoms often mixed up. Soft rot is a serious disease leading to drastic effects on crop (Bhai et al., 2005; Senapati and Ghose, 2005). The rhizome rot disease management involves cultural, biological and chemical approaches for suppression of the pathogens. However, the control of the disease by the use of chemical agents is not so beneficial due to high cost, breakdown of resistance, residual problem and deleterious effect on non-target organisms including humans. This has necessitated search for alternatives for controlling the rhizome rot of ginger (Bhai et al., 2005; Pandey et al., 2010). Plants have been shown to possess inhibitory effect against fungi causing rhizome rot of ginger. Sagar et al. (2007) showed the fungitoxic efficacy of some plant extracts against $P$. aphanidematum \& $F$. solani isolated from rhizome rot specimen of ginger. It was found that Azadirachta indica and Ferula asafeotida showed maximum inhibition of mycelial growth of $P$. aphanidermatum and $F$. solani respectively. In an earlier study, we have shown the potential of ripe and unripe pericarp extract of Polyalthia longifolia against $P$. aphanidermatum and $F$. solani isolated from ginger rhizome rot (Dileep et al., 2013). 
Rakesh et al.,

It has been shown that cow urine based extracts of plants have been reported to possess marked antibacterial and antifungal activity. The extract of Calotropis procera, in combination with cow urine, has shown $91 \%$ inhibition of conidial germination of Bipolaris sorokiniana, causative agent of leaf blight of wheat (Akhter et al., 2006). Tiwari and Das (2011) found in vitro and in vivo inhibitory efficacy of some medicinal plant extracts prepared in cow urine against Rhizoctonia solani, causal agent of sheath blight of rice. Murugan et al. (2012) showed the efficacy of cow urine and cow urine with Pongamia pinnata seed against bacterial leaf blight of paddy caused by Xanthomonas oryzae pv. oryzae. In the present study, we have evaluated the inhibitory effect of cow urine extract of 9 plants against $P$. aphanidermatum and $F$. oxysporum by poison food technique. Reduction of colony diameter of test fungi was considered as antifungal effect of the extracts. It has been observed that the susceptibility to cow urine extracts of plants was higher in case of $F$. oxysporum. The extracts were also effective against $R$. solanacearum.

\section{CONCLUSION}

A marked inhibition of rhizome rot pathogens by cow urine extracts of selected plants was observed in this study. The extracts may find a possible use in agriculture as potent agents against pathogens. Further studies involving field trials is needed to justify the results of the present study.

\section{ACKNOWLEDGEMENTS}

The authors express thanks to Head, Department of Microbiology, Principal, SRNMN College of Applied Sciences, Shivamogga for providing all the facilities to conduct work. Authors also express thanks to NES, Shivamogga for giving moral support.

\section{REFERENCES}

Abubakar, U., Adamu, T., Manga, S.B. (2004). Control of Meloidogyne incognita (kofoid and white) chitwood (root-knot nematode) of Lycopersicon esculentus (tomato) using cow dung and urine. African Journal of Biotechnology 3(8): 379-381.

Akhter, N., Begum, M.F., Alam, S., Alam, M.S. (2006). Inhibitory effect of different plant extracts, cow dung and cow urine on conidial germination of Bipolaris sorokiniana. Journal of Bio-Sciences 14:87-92.

Bajpai, V.K., Shukla, S., Kang, S.C. (2008). Chemical composition and antifungal activity of essential oil and various extract of Silene armeria L. Bioresource Technology 99:8903-8908.

Basak, A.B., Lee, M.W., Lee, T.S. (2002b). In vitro inhibitory activity of cow urine and dung to Fusarium solani f.sp. cucurbitae. Mycobiology 30(1):51-54.
Sci. Technol. Arts Res. J., April-June 2013, 2(2): 92-96

Basak, A.B., Lee, W.M., Lee, T.S. (2002a). Inhibitive activity of cow urine and cow dung against Sclerotinia sclerotiorum of Cucumber. Mycobiology 30(3):175179.

Benkeblia, N. (2004). Antimicrobial activity of essential oil extracts of various onions (Allium cepa) and garlic (Allium sativum). LWT 37:263-268.

Bhai, R.S., Kishore, V.K., Kumar, A., Anandaraj, M., Espen, S.J. (2005). Screening of rhizobacterial isolates against soft rot disease of ginger (Zingiber officinale Rosc.). Journal of Spices and Aromatic Crops 14(2):130-136.

Bhardwaj, S.K., Singla, S.K., Bhardwaj, R.K. (2011). Potential use of some petal extracts against Xanthomo nas campestris pv. campestris. Our Nature 9:100-106.

Burubai, W., Eribo, M. (2012). Influence of incubation periods and dosage on the bioefficacy of cow urine against melon aphids (Aphis gossypii) \& pickleworms (Diaphania hyalinata) in watermelon cultivation. Research Journal of Applied Sciences, Engineering and Technology 4(4): 269-272.

Dake, G.N., Edison, S. (1989). Association of pathogens with rhizome rot of ginger in Kerala. Indian Phytopathology 42(1):116-119.

De Britto, A.J., Gracelin, D.H.S., Sebastian, S.R. (2011) Antibacterial activity of a few medicinal plants against Xanthomonas campestris and Aeromonas hydrophila. Journal of Biopesticides 4(1): 57-60.

Dileep, N., Junaid, S., Rakesh, K.N., Kekuda, P.T.R., Nawaz, N.A.S. (2013). Antifungal activity of leaf and pericarp extract of Polyalthia longifolia against pathogens causing rhizome rot of ginger. Science, Technology and Arts Research Journal 2(1): 56-59.

Gururaja, M.P., Joshi, A.B., Joshi, H., Sathyanarayana, D., Subrahmanyam, E.V.S., Chandrashekar, K.S. (2011). Antidiabetic potential of cow urine in streptozotocin-induced diabetic rats. Asian Journal of Traditional Medicines 6(1): 8-13.

Kavyashree, R. (2009). An efficient in vitro protocol for clonal multiplication of Ginger- var. Varada. Indian Journal of Biotechnology 8: 328-331.

Kekuda, T.R.P., Raghavendra, H.L., Swathi, D., Venugopal, T.M., Vinayaka, K.S. (2012). Antifungal and cytotoxic activity of Everniastrum cirrhatum (Fr.) Hale. Chiang Mai Journal of Science 39(1):76-83.

Krishnamurthi, K., Dutta, D., Sivanesan, S.D, Chakrabarti, T. (2004). Protective effect of distillate and redistillate of cow's urine in human polymorphonuclear leukocytes challenged with established genotoxic chemicals. Biomedical and Environmental Sciences 17: 247-256.

Kumar, A., Reeja, S.T., Bhai, R.S., Shiva, K.N. (2008). Distribution of Pythium myriotylum Drechsler causing soft rot of ginger. Journal of Spices and Aromatic Crops 17(1): 5-10. 
Rakesh et al.,

Murugan, A.M., Shanthi, S., Arunachalam, C., Sivakumar, N., Elamathy, S., Rajapandian, K. (2012). Study on cow urine and Pongamia pinnata Linn seed in farmyard: A natural, cost effective, ecofriendly remedy to bacterial leaf blight (BLB) of paddy. African Journal of Biotechnology 11(40): 9591-9598.

Ojala, T., Remes, S., Haansuu, P., Vuorela, H., Hiltunen., Haahtela, K., Vuorela, P. (2000). Antimicrobial activity of some coumarin containing herbal plants growing in Finland. Journal of Ethnopharmacology 73: 299-305.

Pandey, A.K., Awasthi, L.P., Srivastva, J.P., Sharma, N.K. (2010). Management of rhizome rot disease of ginger (Zingiber officinale Rose L.). Journal of Phytology 2(9): 18-20.

Paret, M.L., Cabos, R., Kratky, B.A., Alvarez, A.M. (2010). Effect of plant essential oils on Ralstonia solanacearum Race 4 and bacterial wilt of edible ginger. Plant Disease 94(5): 521-527.

Rajapandiyan, K., Shanthi, S., Murugan, A.M., Muthu, G.A., Singh, A.J.A.R. (2011). Azadirachta indica - cow urine extract, a novel controlling agent towards clinically significant multidrug resistant Pathogens. Journal of Applied Pharmaceutical Science 01(10): 107-113.

Ranaware, A., Singh, V., Nimbkar, N. (2010). In vitro antifungal study of the efficacy of some plant extracts for inhibition of Alternaria carthami fungus. Indian Journal of Natural Products and Resources1(3):384386.
Sci. Technol. Arts Res. J., April-June 2013, 2(2): 92-96

Sagar, S.D., Kulkarni, S., Hegde, Y.R. (2007). Management of rhizome rot of ginger by botanicals. International Journal of Plant Science 2(2):155-158.

Senapati, A.K., Ghose, S. (2005). Screening of ginger varieties against rhizome rot disease complex in eastern ghat high land zone of Orissa. Indian Phytopathology 58(4): 437-439.

Sharma, B.R., Dutta, S., Roy, S., Debnath, A., Roy, M.D. (2010). The effect of soil physic-chemical properties on rhizome rot and wilt disease complex incidence of ginger under hill agro-climatic region of West Bengal. Plant Pathology Journal 26(2): 198-202.

Tiwari, R.K.S., Das, K. (2011). Inhibitory effect of cow urine based plant extracts against Rhizoctonia solani causing sheath blight of rice. Indian Phytopathology 64(3): 265-268.

Yadav, H., Yadav, M., Jain, S., Bhardwaj, A., Singh, V., Prakash, O., Marotta, F. (2008). Antimicrobial property of a herbal preparation containing Dalbergia sissoo and Datura tramonium with cow urine against pathogenic bacteria. International Journal of Immunopathology and Pharmacology 21(4): 10131020.

Zhao, X., Mei, W., Gong, M., Zuo, W., Bai, H., Dai, H. (2011). Antibacterial activity of the flavonoids from Dalbergia odorifera on Ralstonia solanacearum. Molecules 16: 9775-9782. 